\title{
EXPATRIATION ATHLETES IN SOCCER AND VOLLEYBALL: THE STATE OF THE ART
}

\author{
Ivan Wallan Tertuliano ${ }^{1}$ \\ Anhembi Morumbi University, São Paulo, Brazil \\ Bruna Alves Santana ${ }^{2}$ \\ Adventist University, São Paulo, Brazil \\ Vivian de Oliveira ${ }^{3}$ \\ University Center IESB, Brasília, Brazil \\ Afonso Antonio Machado ${ }^{4}$ \\ São Paulo State University, Rio Claro, Brazil \\ José Maria Montiel ${ }^{5}$ \\ São Judas Tadeu University, São Paulo, Brazil
}

\begin{abstract}
The number of athletes acting outside their countries of birth grows every year, as do those who also choose to defend another national team. Faced with this phenomenon, the objective of this study was to conceptualize the process of expatriation in two sports (Soccer and Volleyball) through an essay, in which qualitative research was used from the perspective of documentary analysis, pointing out the state of the art in this subject. The results indicate that the main reasons given by athletes to justify the expatriation process are economic and professional, such as salary and career opportunities improvement. On the other hand, the difficulties found by athletes in the process are closely related to the lack of family with the athlete after expatriation. With this, the literature points to the need for multidisciplinary preparation and monitoring for those who decide to leave their country, to avoid damages in sports performance.
\end{abstract}

Keywords: Expatriation, Globalization, Sports, Athletes

\section{INTRODUCTION}

Globalization and the new business dynamics of sport have made the number of athletes who leave their countries for professional reasons increasing (Tertuliano, Oliveira, \& Santana, 2019). Football is the modality where the exchange of countries by athletes is most evident, as can be seen in the data of the Brazilian Football Confederation between 2003 and 2013. In 2003 there were 804 players who left Brazil and in 2013 there were 1.530, an $87 \%$ increase in the number of players "exported" and marketed (Confederação Brasileira de Futebol, 2016).

Tertuliano (2016) points out that Pelé law contributed to this expatriation process through the free pass. Due to Pelé law, athletes and

\footnotetext{
${ }^{1}$ Correspoding author. ivanwallan@gmail.com

2 brunnasantna@gmail.com

3 vivian_oliveira58@hotmail.com

${ }^{4}$ afonsoa@gmail.com

5 montiejm@hotmail.com
} 
clubs do not want to establish long-term contracts, giving the athlete the opportunity to move through different clubs in a short period of time. In addition, the lack of championships or adequate training structures led athletes to the expatriation process. This scenario makes athletes have the need for constant team change, so that they can continue to play the sport, in a competitive and professional way.

Regarding the amounts involved in the expatriation process, Bertolotto (2014) mentions that the expatriation of Brazilian soccer players led in 2013 to an amount of US\$ 277 million dollars, an increase of US\$ 91 million dollars compared to the amount of US\$ 186 million in 2007. However, this expatriation process is not recent and was influenced by the massification of the sport, Football, with society (Rial, 2003).

However, expatriation is not an exclusivity of soccer athletes, as we have reports in the literature of the expatriation process in Volleyball (Pontes, Ribeiro, Garcia, \& Pereira, 2018; Tertuliano, Machado, Deustch, Montiel, \& Bartholomeu, 2018; Tertuliano, Machado, Oliveira, et al., 2018), but with more modest numbers. In 1978 there were 3 expatriate players (Bizzocchi, 2008), in 2006 there were 348 and in 2015 more than 400 players (Confederação Brasileira de Voleibol, 2015).

With regard to athletic expatriation, there are two distinct processes, one that refers to changing teams to continue practicing the sport, but defending the selection itself if it is called, and another that refers to representing the selection of another country (Tertuliano, 2016), that is, in addition to expatriating, the athlete changes nationality. In the case of Football, one can mention the Football World Cup. In 2002 there were 43 athletes who played for countries different from those in which they were born, in 2006 there were 65 athletes, in 2010 there were 74 athletes and in 2014 there were 94 athletes (Reis, 2014; Teixeira, 2014).

When talking about the first expatriation process (playing outside the home country, but defending if called up), playing in other countries, especially in developed countries, represents a dream for many athletes, but this is not an easy process. Given the above and facing the complexities of the theme, the objective of the present study was to conceptualize the expatriation process in two sports (Soccer and Volleyball), pointing out the state of the art of this theme in order to present the main documentary studies that dealt with the area.

In order to present and propose academic-professional postures, this essay aimed to present a state of the art direction of athletic expatriation, using classical and contemporary studies to construct reflection on the theme. Thus, this essay was based on the methodological design of a qualitative research from the perspective of documentary 
analysis (Marconi \& Lakatos, 2017), with the objective of expanding knowledge about the theme.

\section{THE FIRST BRAZILIAN EXPATRIATES: FOOTBALL}

Brazil is one of the countries that exports the most athletes, especially in Football (Rial, 2008; Rodrigues, 2010). Some statistics reinforce the evolution of the expatriation process. Between 1992 and 2005, Brazil had an increase in the flow of expatriate athletes in the house of $392 \%$ in Soccer. In 2006, Brazil exported 851 football players to foreign teams, in 2008 there were 1.176 players, in 2010 there were 1.029 players, in 2012 there were 1.463 players and in 2013 there were 1.530 players(Confederação Brasileira de Futebol, 2016).

Although Brazilian football evolved in 1950, in terms of visibility, expatriation began well before. It comes from the time when defending Brazil was a boy's dream (Teixeira, 2014). One of the first Brazilians to leave Brazil to defend another team was Filó in 1931, leaving Corinthians and going to Italy to defend Lazio. Filo was the right name for the 1930 World Cup in Uruguay, however, due to the issues of fights between top hats, he stayed out of the World Cup. Disappointed with his exclusion from the Brazilian national team and the 1930 World Cup, Filó accepted in 1931 a transfer proposal to Italian Football, agreeing with Lazio his transfer.

Filó was so successful in the Italian league that the following year his arrival at Lazio he was invited to become naturalized, and accepted the invitation. Due to his excellent italian football campaign for Lazio, Filó was called up to defend the Italian national team at the 1934 Fifa World Cup, which had been held in Italy. Filó participated only in Italy's first world cup game and followed the Italian national team from the bench, being the first Brazilian to be World Champion (Teixeira, 2014).

Thus, understanding expatriation in Soccer is difficult, it refers to the understanding of different variables. One of the possible variables is the large number of boys who want to become professional players and the amount of opportunities they have. Grassroots clubs make up millions of players, but few go so far as to become professional athletes. Thus, it is evident that there is not enough space, within the national scenario, for all possible professional soccer athletes, especially in the best Football Clubs in Brazil. According to the CBF, in 2014 there were 783 football clubs registered in Brazil and 13.639 registered professional players.

In view of the above, expatriation has existed since the first decades of the 20th century, but accelerated after 1996, due to the change in European legislation post-bosman case (Rial, 2008; Tertuliano,

Vol. 22, бpoj 2/2020, cmp. 31-50 
Oliveira, Pavlović, \& Machado, 2018). After 1996, the mobility of football players, in the international context, grew and the percentage of foreigners in European football leagues as well.

According to the Globo Esporte website (Globoesporte, 2013), in 2012 only $21,1 \%$ of European soccer athletes were trained in the clubs where they played, the lowest number ever recorded. In this context, Brazil leads the ranking of countries with the highest number of expatriate players in the European leagues, followed by Argentina and Serbia (Andreff, 2010). Allied to this, the Pelé Law (Law 9.615/98) was also one of the factors that contributed to the growing rise of Brazilian expatriates in the 21 st century, because it instituted the free pass.

Before Pelé law, the pass was the link between the player and the club, after the law, the pass was replaced by a labor and sports bond, giving the player the right to sign a contract with a team, even already hired by another, upon payment of a fine. For athletes, Pelé law contributed to expatriation, because the club is no longer the only one with the power to decide about the future of athletes. The big question about this law is that players begin to leave the country with an age of less and less, having departures under the age of 18 (Andreff, 2008).

Due to Pelé law, athletes and clubs do not want to establish longterm contracts, giving the athlete the opportunity to move through different clubs in a short period of time. According to Rial (2008) and Pisani (2010), the circulation of the main names of Brazilian football passes through the major football business centers such as England, Spain, Italy, Germany and the United States (USA), in the case of women (Pisani, 2014). However, other countries, such as Canada, Japan, Vietnam, Iran, etc., increase their insertion in the market of expatriations of Brazilian players (Rial, 2008; Teixeira, 2014).

\section{3. "I'M GOING TO PLAY ABROAD": THE REASONS FOR EXPATRIATION}

Grassroots clubs make up millions of players, but few go so far as to become professional athletes. This is because there is not enough space, within the national scenario, for all possible professional soccer athletes, especially in the best Football Clubs in Brazil. Another factor that may explain this growing number of expatriate soccer players is purely economic and concerns the salary of Brazilian football.

Approximately $82 \%$ of professional athletes in Brazil earned up to two minimum wages (Teixeira, 2014) and in addition, many clubs delay salaries and prizes that should be paid to athletes, demotivating the athlete to stay in the club and causing him to look for "new airs". Many of the 
clubs do not pay salaries on time and ignore the payment of prizes to athletes, demotivating the athlete to stay in the club and leading him to look for "new airs".

The lack of payment of salaries and prizes is often linked not only to the lack of revenue of the club, but mostly to schooling. The fact that football players have a low level of education - because most boys "give up" their studies to "play ball" - is a favorable element for this to occur (Rodrigues, 2010), leaving the athlete vulnerable to the precariousness of work and the action of malicious agents and leaders.

It is also observed the lack of championships or adequate structures for training. This scenario makes athletes have the need for constant team change, so that they can continue to play the sport, in a competitive and professional way (Faggiani et al., 2016; Fontes, 2011), even if this change leads to a change of nationality (Teixeira, 2014).

For Fontes (2011), changing teams is not a matter of lack of love for the shirt, but a need that some sports, such as men's sand soccer and women's field soccer, impose on athletes. As there is no calendar with championships throughout the year, it is difficult to maintain a contract with the same team throughout the season. For example, the Sand Soccer Athlete Bruno Malias, in 2011, defended 5 teams from different regions. Another example is Athlete Benjamin who defends Corinthians (Brazil) and Milano (Italy). In these contexts, expatriation is a nomadic process, as athletes constantly change teams.

But it should be pointed out that football is practiced by men and women, which leads us to understand how this occurs in Women's Football. Women's football is only 35 years old, which makes it relatively younger than men's football and less competitive, as Pisani points out " In the São Paulo Women's soccer Championship we can find 18 teams competing in the 2012 edition, against 8 teams in the 2012 Rio de Janeiro Women's soccer Championship and 5 teams in the 2011 Paraná Women's soccer Championship" (Pisani, 2014, p. 2).

Pisani (2014) also points out that a player from the western state of Paraná, who acts in the position of starting striker, receives only $2 \%$ of the salary of a man, who acts in the same team and position. In this way, like the male player, the soccer player ventures into new countries and clubs in order to improve her living condition. However, dealing with expatriation in women's soccer is not simple, because there is little information and the Brazilian Football Confederation (CBF) does not contribute information regarding the departure and return of players.

Probably, this lack of interest is due to the fact that soccer players have little value in the market, compared with male players, in addition to the financial non-circulation during the hiring and transfers of clubs by 
the athletes. Given the scenario exposed, some studies were conducted (Freitas et al., 2012; Machado, 2013; Rial, 2008; Rodrigues, 2010) with the objective of understanding the process of expatriation of athletes.

Rial (2008) aimed to analyze, from an anthropological perspective, the expatriation processes of Soccer players, seeking to understand the characteristics of this world circulation. To achieve these goals, the author interviewed 40 Brazilian players who lived or lived in countries abroad. The author found some interesting results, such as the large number of players being the youngest of the family (the youngest), rare were the firstborn, because many abandoned this project to contribute to the family economy. Most of the players interviewed had only elementary school. All participants associated their economic improvement with Football and a divine factor ("God wanted it so").

Almost all participants used their first salary, abroad, to buy a house for their mother or for a retirement, when the mother did not want to leave the house in which she lived. All interviewees considered themselves the providers of their families, supporting them. Most of the players came out of humble, evangelical families. Each year the age of expatriate players decreases, which the author called the juvenilization of this process. The author concludes that the constant exchange of club, country and the large number of returnees is something that players attribute as positive for the career, because it provides experience, as long as it is between large clubs.

Rodrigues (2010) aimed to analyze the influence of the end of the pass on the transactions of soccer players in Brazil. For this, the author applied 97 questionnaires with soccer athletes of series A, B and C of the Brazilian championship. The results of the research pointed to the creation of new conditions for external transfers of Brazilian players from the end of the pass. This led to a significant growth in international player transfers, accentuating the expatriation of Brazilian athletes.

More than that, the results pointed to a regular schooling, and $64,9 \%$ of the interviewees presented educational degree in high school. The participants showed an improvement in salary, with salaries between 7 and 10 minimum wages. The author concluded that football clubs function as transnational companies that consolidate the international trade in athletes and that the expatriation of players is related to several factors such as economic, political, administrative, cultural, etc. 


\section{BETWEEN THE DREAM AND REALITY: THE DIFFICULTIES OF THE PROCESS}

There are many difficulties that the athlete can encounter away from home and that must be presented. In order to understand the problems involving Brazilian athletes abroad, that is, to analyze the main factors that hinder adaptation abroad, Freitas et al. (2012) conducted a field study. Ten former soccer athletes who worked abroad participated in the research. Of these, three acted professionally and seven in an amateur manner, that is, they intersboded football with another job. The participants answered a simple, clear and objective questionnaire with predefined questions. The results were analyzed quantitatively by percentage use.

According to the results, $40 \%$ of former athletes pointed to discrimination or distrust as the main obstacle abroad, $50 \%$ pointed to religion as a cultural aspect of greater difficulty in adapting, 100\% support the presence of family or friends to facilitate adaptation to the new country, $70 \%$ thought they had a good life in the club, $80 \%$ assumed that the relationship with the other athletes of the club influenced the adaptation, $40 \%$ said that training and competition conditions, when precarious, make adaptation difficult and $60 \%$ classified their experience in another country as good. In view of the results, the authors concluded that the psychological factor has an enormous weight in terms of adaptation in the midst of a new culture and that the presence of family or friends are fundamental pieces in the athlete's adaptation to the new country.

Richardson et al. (2012) investigated the migration process of young football players in the English Football League. For this, five young players were interviewed, who made the migratory transition between 16 and 24 years of age. The interviews were analyzed using the principles of content analysis. In view of this, the results indicate that young migrants face the initial frenzy associated with an approach of an English league club before going through a "decision" phase, followed by a period of "migration" and "acculturation" before establishing (or not) the "home".

The authors concluded that the challenges of leaving home and family, while athletes try to establish themselves as a professional player in an environment that seems to be involved with the traditional culture of English football, that is, high rhythm, cruel, sexist and aggressive are apparent today. In addition, the authors mention that there is a need for qualified professionals for the proper training of soccer athletes and agents, in order to support young players in migration.

Vol. 22, бpoj 2/2020, cmp. 31-50 
Agergaard \& Ryba (2014) proposed a transactional model and athletic careers, according to a psychological and sociological perspective. The authors interviewed 18 athletes ( 8 African and 10 North American), who had been working for at least one year in the main Danish, Norwegian or Swedish women's soccer leagues between 2009 and 2011, aged between 23 and 34 years.

They then identified three normative career transitions for transnational athletes: the first would be transnational recruitment, which is based on individual agencies and also on social networks; secondly, there is the establishment as a transnational athlete, which relates to cultural and psychological aspects of adaptation, as well as the feeling of belonging; finally, the end of the athletic career, which for transnational athletes is connected to a (re)constitution of the transnational network of sense of belonging.

Weedon (2011) investigated the experiences of acculturation of young Football players after making migrations to Premier League clubs ,which the author calls "Glocal Boys". This investigation was conducted with interviews with young migrants from a variety of cultural and ethnic backgrounds and their "acculturation groups", including directors, managers and coaches. The results showed that migrant athletes must adjust to the cultural, physical, etc. demands of the club. Thus, the author concludes that the acculturation process as the experiential facet of the globalization thesis reflects the interaction between the political economy and the individual experiences of acculturation of each athlete.

Machado (2013) aimed to identify and analyze how the processes of expatriation and repatriation of players are structured in football clubs, and how these processes are perceived and conducted in the face of the reality of Brazilian sports management. Twenty-two people participated in the study, ten soccer athletes, six soccer entrepreneurs and six managers of gaucho football clubs. The participants were conducted by a qualitative research, through semi-structured interviews. The author analyzed the interviews through content analysis.

The results obtained were as follows: (a) with the change in the management of clubs and the scenario of expatriation and repatriation of players, there is the possibility of new ways to manage these processes and participation of clubs in the management of their sports talents; (b) clubs can align their management with the planning and management of the player's career, even aiming at profit, however one should take into account a strategic vision of management, including the management of people in sport and the management of sports talent, not only the vision of product and profitability on its marketing; (c) there are great possibilities to create policies and practices of strategic management of people in the 
field of sport, when considering the new scenario. The author concluded that these new conceptions and managements of people can contribute to a substantial gain for clubs and players, increasing financial return and performance, reducing failure in the processes of expatriation and repatriation.

Tibbert et al. (2015) investigated how the norms, traditions, ideals and imperatives of a subculture influenced the attitudes, beliefs, emotions and behaviors of a young Football athlete in the expatriation process. This study had a case study design, with the participation of a young soccer athlete, who was followed for 14 months, through 5 interviews. The results of the interviews showed that the young athlete, in the initial interviews, resisted the demands of the football club's subculture and tried to find success by maintaining his own beliefs.

At the end of the study the young man realized that to be successful in the club he needed to accept the norms, traditions, ideals and imperatives of football culture. Thus, the young man gained acceptance in the club and, in addition, after accepting the culture of the new club, the young man considered physical abuse as a positive and necessary part of the hardening process. The authors concluded that athletes, in order to get space in the clubs, must submit to their culture, demonstrating that without pain there is no gain and that success is more important than individual well-being.

Faggiani et al. (2016) conducted a systematic review seeking to identify the terms used to refer to the process of moving from region/country to sports practice, in addition to seeking to understand the impacts that the individual suffers in the face of adaptation to a new reality. The authors found that there is no single term to define the transition process of athletes between different cultures, and "migratory transition", "migration", "acculturation" are some of those used.

It was also found that, although individuals see the process as something positive, they encounter challenges related to adapting to the new style of training and local culture, distance from family members and other loved ones, to difficulties in communicating with family and friends, as well as the difficulty in communicating with other people to establish relationships. These difficulties were pointed out by the authors as situations that can interfere in mental health and also in the sports performance of these athletes.

Faggiani (2017) sought to understand the acculturation process, identifying the related aspects, as well as understanding the transition process to adulthood and emerging adulthood in Soccer athletes. As main results, the author highlights that $63 \%$ of the athletes surveyed presented deficits in social skills after six months of the acculturation process, with 
emphasis on coping and self-exposure factors. Young athletes presented minimal symptoms of anxiety, depression and stress.

Some difficulties were reported by the athletes, such as the lack of people known on arrival to the new team, the characteristics of the region (such as food, climate, etc.), in addition to the distance from the family. The athletes also mention the difficulties for adapting to different types and dynamics of training. They also comment on the importance of communication technologies for interaction with family and friends. The author concluded that the age of the athletes and the prospects for the future seem to be predictors of emerging adulthood.

\section{THE DECISION TO "CHANGE THE SHIRT": IN ADDITION TO THE EXCHANGE OF CLUBS}

In many cases, the athlete not only changes teams, but also the nation he represents in international competitions between teams. Reis (2014), as of May 15, 2014, for the UOL website, presented the following statistics: At the 2006 World Cup, we had 5 Brazilians defending other nations, in 2010 there were 6 and in 2014 there were 7. The number of soccer athletes who defend other countries in World Cups grows with each World Cup. At the 2002 World Cup there were 43 athletes, in 2006 there were 65 athletes, in 2010 there were 74 athletes and in 2014 there were 94 athletes (Reis, 2014; Teixeira, 2014).

Faced with this new dynamic, Tiesler (2016) sought to conceptualize an "umbrella" categorization based on the migration of soccer players, considering the experience in at least two different countries and sociocultural contexts. The author states that transnational players are those who have experience working in different countries and socioeconomic contexts. The author highlights three types of transnational athletes: expatriates, diasporas and new citizens.

Expatriates are players who leave the country where they grew up after recruiting a club abroad. The diasporas are those who were born and socialized in advanced football systems and provide their skills to the national team of their parents' country of origin, and cannot be considered migrants, as they continue to live and play soccer in their country of birth, not involving migration. The new citizens are those who become naturalized after the invitation of a football federation abroad, and to join their selection, will hardly be considered an expatriate. Unlike diaspora players, they have no ancestors in the country in which they obtain citizenship and generally have no prior connection (Tiesler, 2016).

In the case of Brazil. possibly the lack of space for new players can be considered a motivating factor of the change of nationality. The 
great competition in Brazilian football means that there is no room for everyone to dream about the Brazilian national team. According to Teixeira (2014), Brazil has about 13,639 players working in Brazil and more than 1,500 who work outside Brazil. In addition, the possibility of winning a "free passport" on the European market, i.e. free transit in EU countries; and the very process of globalization that came to break down barriers and allow Brazilians to spread to the most distant countries in the world, may be some factors that favor the change of nationality.

In summary, according to Rial (2008), even acquiring the nationality of another country, the football player continues to feel like a foreigner, as well as the society of that country sees him as a foreigner. As observed, expatriation in Football is discussed in the literature (Brandão, Magnani, Tega, \& Medina, 2013; Faggiani et al., 2016; Fontes, 2011; Machado, 2013; Rial, 2008; Teixeira, 2014; Tertuliano, Oliveira, Pavlović, et al., 2018; Tiesler, 2016; Weedon, 2011), but in other sports the discussion is smaller (Agergaard, 2008; Andreff, 2008; Tertuliano, 2016; Tertuliano, Machado, Deustch, et al., 2018; Tertuliano, Machado, Oliveira, et al., 2018; Tertuliano, Oliveira, et al., 2019).

\section{MARKET DYNAMICS AND EXPATRIATION CASES IN VOLLEYBALL}

Expatriation is not exclusive to football and also occurs in other sports, such as Volleyball. In Brazil, Volleyball is a sport that moves crowds to gyms and millions in revenues (box office, broadcasts and sports materials). Thus, Volleyball is the second most popular sport in Brazil, only losing to Football.

Volleyball gains new practitioners and fans every day, which opens the interest of a large financial market. All popularization of Volleyball occurred from the increase of the television transmission of the sport (Marchi Júnior, 2005). Thus, Volleyball is a plural sport and, with this, it is present in several sociocultural contexts, with different purposes (Lopez, 2012; Lopez \& Silveira, 2012).

For Machado (2014), most of the time the first contact with the sport is in school. For Lopes \& Silveira (2012), Volleyball is used in school as content of the discipline of Physical Education, but can be practiced in moments of fun or leisure and by people of different ages. In addition to practice, Volleyball is a product of entertainment, that is, watched as a spectacle (Lopez \& Silveira, 2012; Marchi Júnior, 2005), or even as a profession (volleyball athletes, managers, coaches, etc.).

As a product, Volleyball is seen by numerous entrepreneurs as a product that can be allied to its brand and, with this, increase its revenue.

Vol. 22, бpoj 2/2020, cmp. 31-50 
Allied to this, Marchi Júnior (2005), in his study, shows that more than half of the American population (60\%) prefers to watch sports on television. In Brazil, according to Fraga (2014), in a survey conducted by the mintel website, $44 \%$ of adult Brazilians who plan to follow the 2016 Olympic Games in Rio de Janeiro intend to attend volleyball games. According to the study, interest in Volleyball is higher in classes with higher purchasing power (Classes A and B), with $50 \%$ of class A and B people planning to follow volleyball matches, while $33 \%$ of Class $\mathrm{C}$ and $38 \%$ of Class D plan to watch volleyball games.

All the actions of the Brazilian Volleyball Confederation (CBV) and the International Volleyball Federation (FIVB) caused volleyball to enter the hall of the desired sports worldwide, spectacularizing it. In this way, the increase in volleyball communication on television ended up "awakening" interests and bringing together a large number of people to watch the television broadcasts of Volleyball, which has caused a particular interest in private companies in Brazilian Volleyball since the 1980s (Marchi Júnior, 2005).

In addition to all these actions are the actions of the investors themselves, who saw in Volleyball a great means of advertising return and, moreover, less costly to companies, when compared to conventional marketing costs (Television and Radio). A good example for given information is the case of the Team Sadia Sport Club. In a study conducted by The SADIA Group, in 1988 and 1989, during 1 year of investments, the team obtained the following results: in 1 year of analysis, the team's marketing and maintenance expenses totaled U\$ 569.358,00. On the other hand, the expenses with institutional advertising of the Sadia brand, in four television networks and eleven newspapers, reached the sum of U\$ 1.805.522,00 (Manta, Trade, \& Pinto, 1989).

The SADIA Group demonstrated as positive the result of the market return that the Sadia Esporte Clube team brought to the brand, assuming the sport as an investment and brand support. Corroborating these findings, the authors Vlastuin et al. (2008) describe the importance of investment by companies in this new marketing, claiming that companies that invest in conventional advertising treat monotonously the relationship with customers and run the risk of having the competitor selling their product in the same space soon after, justifying the importance of new means of marketing, with sporting events, in our case, Volleyball.

The companies' search to combine their brand with Volleyball has ensured a greater potential for the commercialization of Volleyball, due to the generation of greater possibilities of commercialization of sporting events by clubs and federations (Vlastuin et al., 2008), given the great 
international level of competitiveness that some clubs have, generating greater interest by the public and companies. With this, Volleyball came to be considered as Sport-Spectacle, that is, the sport of high performance transformed into merchandise (Costa, 2007).

Based on the above-mentioned principle, it is possible to understand the context in which sport presents itself in today's society. Volleyball is a modern sport that offers great opportunities for competition, but generates specialization of roles, rationalization and bureaucratic organization, all in search of records (Guttmann, 2004). In view of this growing participation of volleyball in society, as well as sports as a whole, there was a need for regulation as a practice of it.

In the case of the practitioner of the performance sport, that is, the athlete, in this conception of merchandise, it is noted that volleyball is not different from other sports, that is, the athlete becomes a commodity of the sport-spectacle. Amateurism in Volleyball has been behind us since the 1980s, but it is in the 21st century that the aggressiveness of businessmen and clubs has reached its peak, making the athlete a mere commodity and bargaining chip (Pisani, 2014). According to Rubio (2010), athletes have sought to respond to the demands of recent years and the best have been transformed into goods, sold and traded around the world.

These sales and negotiations lead the athlete to change countries, culture, etc. This has occurred in Brazilian volleyball since 1960, when Brazil began to gain recognition on the world stage, due to victories by the Brazilian volleyball teams (Bizzocchi, 2008). This led to brazilian players William Silva, Bernard Rajzman, Montanaro and Bacalhoca being hired to play in the Italian league in 1978. Currently, according to the Brazilian Volleyball Confederation (2015), there are more than 400 registered athletes working outside the country. According to the UOL website, with an article published on December 10, 2006 (UOL, 2006), in 2006 there were 348 athletes working outside Brazil and this occurred because some European clubs even pay up to US\$ 650.000 in salary, in addition to home, car and passage to the athlete's family.

In view of the above, the commercialization of Volleyball players became inevitable, that is, the expatriation of athletes. However, one of the limitations of the literature on the expatriation of athletes in Volleyball is the scarcity of studies on the subject. Tertuliano (2016) investigated the reasons that lead volleyball athletes to return to their country of origin after the expatriation process. In this research, the author used athletes and former volleyball athletes, who answered questions pertinent to the objective. 
To respond to the objective, the author analyzed only the athletes who played in teams from other countries. The results showed that the return of athletes to their country of origin was related to family longing or career ending. The author concluded that the most relevant reason for athletes to return to their country of origin is the family, which demonstrates a need for expatriation programs that include the athlete's family (Tertuliano, Montiel, Deutsch, \& Machado, 2019).

Tertuliano, Machado, Deustch, et al. (2018) investigated what are the factors that lead the Volleyball athlete to change countries and teams throughout his career. For this, it investigated 48 athletes and 20 former athletes, 43 men and 25 women. The authors used a questionnaire with open and closed questions. The results indicate that what most motivated the athletes' departure from the expatriation process was the search for salary improvement, and that this is a process well seen by athletes. In view of these results, the authors concluded that the determining factor for expatriation is the improvement of salaries.

In another study with the same experimental design Tertuliano, Machado, Oliveira, et al. (2018) sought to understand the adaptation of volleyball athletes after a process of moving to a new club, either in their own country or in another country. The results showed that the athletes presented satisfactory adaptation to the new club, caused especially by the relationship with the athletes of the new team, coaches and other members of the technical committee, regardless of whether expatriation is in the same country or to another country. The results allowed the authors to conclude that the athletes developed adequate strategies to cope with the new context they were inserted, that is, the new club and that this adaptation was favored by the reception they received in the new club.

Pontes et al. (2018) conducted a study, with the objective of analyzing the discourse of high-performance volleyball athletes and coaches on the migration process in this modality. For this, they conducted an analysis of the discourse based on interviews conducted with two coaches and eight athletes from the Unilever/RJ and RJX/RJ teams. Supported by the interviews, the authors highlight that coaches are concerned about the need to find good athletes and that they are in accordance with financial management. For athletes, migrating represents a leap in professional development, a social rise through salary improvement, and also as an opportunity to develop and improve their technical qualities, increasing their experience and maturity as an athlete. In addition, for athletes some personal factors, such as knowing other countries and cultures, are taken into consideration at the time of choice. 


\section{FINAL CONSIDERATIONS}

In the present essay, it is observed that athletic expatriation in both sports (Football and Volleyball) has been occurring for many years and is something that will not be reversed. Thus, it can be said that there is a great transition of athletes between regions of the same country (Pisani, 2014; Tertuliano, 2016, 2018) and between countries that have different cultures (Faggiani et al., 2016; Tertuliano, Machado, Deustch, et al., 2018; Tertuliano, Oliveira, et al., 2019), however, the preparation of athletes for this phenomenon is poorly worked, or rather, it is not worked (Agergaard, 2008; Agergaard \& Ryba, 2014; Brandão et al., 2013; Freitas et al., 2012; Garrido, Olmos, Arjona, \& Pardo, 2012; Machado, 2013; Richardson et al., 2012; Sebben, 2009; Tertuliano, Oliveira, Pavlović, et al., 2018; Tertuliano, 2016; Tertuliano, Oliveira, et al., 2019; Tibbert et al., 2015).

As reasons, salary is an important factor for the athlete's decisionmaking for expatriation (Freitas et al., 2012; Tertuliano, Machado, Deustch, et al., 2018; Tertuliano, Oliveira, et al., 2019). In addition, the influence of the coach and the group members are important to adapt the athlete in the new club, and that the family is important in the expatriation process (Brandão et al., 2013; Tertuliano, 2016), demonstrating that there is a need to develop training strategies for the expatriation process in the sports field.

Thus, when preparation strategies are not adequate, the athlete may present acculturation, that is, the athlete cannot adequately interpret the culture of the new country/club, leading the athlete to a wide set of emotional reactions, often unpleasant to the athlete (Faggiani et al., 2016; Pereira, Pimentel, \& Kato, 2005; Tertuliano, Oliveira, Pavlović, et al., 2018; Tertuliano, Oliveira, et al., 2019), such as anxiety (Tibbert et al., 2015) and stress (Brandão et al., 2013).

This set of emotions can hinder the athlete's performance, causing their performance to decline, which can be a big problem at the same time, while performance and maintenance in the club. Examples of this are in studies, where the routine in training (Tertuliano, 2016; Tibbert et al., 2015), the distance from the family (Richardson, Cowan, Callaghan, \& Kan, 2016; Weedon, 2011), the difficulty of the language of the new country (Richardson et al., 2012; Tertuliano, 2016; Weedon, 2011) and the culture shock (Agergaard, 2008; Agergaard \& Ryba, 2014; Faggiani et al., 2016; Richardson et al., 2012; Weedon, 2011) demonstrated as factors that influenced the athlete during expatriation and that most often in a negative way, that is, if the process is not monitored and oriented, it can cause harm to the athlete (Faggiani et al., 2016).

Vol. 22, бpoj 2/2020, cmp. 31-50 
As limitations of the present study are the fact that it is an essay, demonstrating the need for future studies with the objective of expanding the results about the influence of expatriation in the sports context in different sports and cultures, as well as studies that present the results about the strategies adopted in the face of the training of athletes for the expatriation process.

\section{REFERENCES}

1. Agergaard, S. (2008). Elite athletes as migrants in Danish women's handball. International Review for the Sociology of Sport, 43(1), 5-19. https://doi.org/10.1177/1012690208093471

2. Agergaard, S., \& Ryba, T. V. (2014). Migration and Career Transitions in Professional Sports: Transnational Athletic Careers in a Psychological and Sociological Perspective. Sociology of Sport Journal, 31(2), 228-247. https://doi.org/10.1123/ssj.20130031

3. Andreff, W. (2008). Globalization of the sports economy. Rivista Di Diritto Ed Economia Dello Sport, 4(3), 13-32.

4. Andreff, W. (2010). Why Tax International Athlete Migration? The 'Coubertobin' Tax in a Context of Financial Crisis. In J. Maguire \& M. Falcous (Eds.), Handbook on Sport and Migration: Borders, Boundaries and Crossings (pp. 31-45). Oxon: Routledge.

5. Bertolotto, R. (2014). Jogador brasileiro vende mais lá fora do que castanha de caju. UOL Online. 11 jul. 2014. Retrieved May 17, 2015 , from http://copadomundo.uol.com.br/noticias/redacao/2014/07/11/vexa me-na-copa-pode-impactar-exportacao-de-jogador-brasileiro.htm

6. Bizzocchi, C. C. (2008). O Voleibol de Alto Nível: da iniciação à competição. Barueri: Manole.

7. Brandão, M. R. F., Magnani, A., Tega, E., \& Medina, J. P. (2013). Além da cultura nacional: o expatriado no futebol. Revista Brasileira de Ciência e Movimento, 21(2), 177-182. https://doi.org/10.18511/rbcm.v21i2.4143

8. Confederação Brasileira de Futebol. (2016). Transferências internacionais: números de 2015. Retrieved May 17, 2018, from https://www.cbf.com.br/a-cbf/informes/index/transferenciasinternacionais-numeros-de-2015

9. Confederação Brasileira de Voleibol. (2015). Relatorio Anual 2014. Retrieved May 17, 2015, from http://2016.cbv.com.br/balanco/rel_atividades_2014.pdf 
10. Costa, M. M. (2007). Esporte de alto rendimento: produção social da modernidade - o caso do vôlei de praia. Sociedade e Estado, 22(1), 35-69. https://doi.org/10.1590/S0102-69922007000100003

11. Faggiani, F. T. (2017). O processo de aculturação e a adultez emergente em atletas de Futebol. (Doctoral Thesis). Pontífica Universidade Católica do Rio Grande do Sul, Porto Alegre, Brazil.

12. Faggiani, F. T., Strey, A., Fuginiti, D., Lindern, D., Aiquel, P. F., \& Sartori, C. (2016). O Fenômeno do Expatriado no Contexto Esportivo. Psicologia: Ciência e Profissão, 36(3), 738-747. https://doi.org/10.1590/1982-3703001832016

13. Fontes, A. C. (2011). A vida nômade de atletas que vestem camisas de vários times pelo mundo. Retrieved May 17, 2015, from http://globoesporte.globo.com/eventos/futebol-deareia/noticia/2011/07/vida-nomade-de-atletas-que-vestemcamisas-de-varios-times-pelo-mundo.html

14. Fraga, V. (2014). Empresas precisam ficar mais atentas ao potencial do voleibol. Retrieved January 28, 2016, from http://brasil.mintel.com/blog/noticias-estilos-de-vida/empresasprecisam-ficar-atentas-ao-potencial-do-voleibol

15. Freitas, L. P. R., Costa Neto, J. R., Cardoso, R. M., \& Ferreira, M. P. P. (2012). Estudo do fenômeno do regresso de ex-atletas sulmineiros de futebol do exterior. Lecturas: Educación Física y Deportes, 16(164), 1-9.

16. Garrido, A. A., Olmos, J. C. C., Arjona, N. G., \& Pardo, R. (2012). Immigration, school, physical activity and sport. Analysis of sport acculturation in Spain. Kinesiology, 44(1), 83-93.

17. Globoesporte. (2013). Brasil segue como maior exportador de jogadores para os clubes europeus. Retrieved May 15, 2017, from http://globoesporte.globo.com/futebol/futebolinternacional/noticia/2013/01/brasil-segue-como-maiorexportador-de-jogadores-para-os-clubes-europeus.html

18. Guttmann, A. (2004). From ritual to record. New York: Columbia University Press.

19. Lopez, L. A. (2012). Voleibol nas Revistas Motriz e RBCE: A hegemonia da área biodinâmica. In VI Congresso SulBrasileiro de Ciências do Esporte (pp. 1-15). Rio Grande: CBCE.

20. Lopez, L. A., \& Silveira, R. (2012). Produção Científica e Voleibol: Uma pesquisa documental na revista motriz. Revista Didática Sistêmica, Especial(1), 278-291. https://doi.org/10.1007/s13398-014-0173-7.2

21. Machado, A. A. (2014). Voleibol se aprende na escola. Várzea Paulista: Editora Fontoura. 
22. Machado, F. S. (2013). Gestão de pessoas interncional no contexto esportivo brasileiro: uma análise dos processos de expatriação e repatriação de jogadores em um clube de futebol gaúcho. (Masters dissertation). Universidade Federal do Rio Grande do Sul, Porto Alegre, Brazil.

23. Manta, I., Trade, R. A., \& Pinto, M. S. (1989). Avaliação e divulgação do voleibol feminino. Revista Brasileira de Ciência e Movimento, 3(4), 72-76.

24. Marchi Júnior, W. (2005). O processo de ressignificação do voleibol a partir da inserção da televisão no campo esportivo. Revista Brasileira de Ciências do Esporte, 26(2), 149-162.

25. Marconi, M. A., \& Lakatos, E. M. (2017). Metodologia Científica (7th ed.). São Paulo: Atlas.

26. Pereira, N. A. F., Pimentel, R., \& Kato, H. T. (2005). Expatriação e estratégia internacional: o papel da família como fator de equilíbrio na adaptação do expatriado. Revista de Administração Contemporânea, 9(4), 53-71. https://doi.org/10.1590/S141565552005000400004

27. Pisani, M. S. (2010). "Muito samba e pouco trabalho": A representação dos jogadores de futebol brasileiros que atuam no exterior. (Bachelor's Degree). Universidade Federal de Santa Catarina, Florianópolis, Brazil.

28. Pisani, M. S. (2014). Migrações e deslocamentos de jogadoras de futebol: mercadoria que ninguém compra? Esporte e Sociedade, 9(23), 1-11.

29. Pontes, V. S., Ribeiro, C. H. V., Garcia, R. M., \& Pereira, E. G. B. (2018). Migração no Voleibol brasileiro: a perspectiva de atletas e treinadores de alto rendimento. Movimento, 24(1), 187-198. https://doi.org/10.22456/1982-8918.66495

30. Reis, R. (2014). Brasil tem 7 jogadores em outras seleções da Copa. Retrieved May 17, 2015, from http://www1.folha.uol.com.br/esporte/folhanacopa/2014/05/14545 15-brasil-tem-7-jogadores-em-outras-selecoes-da-copa.shtml

31. Rial, C. (2003). Futebol e mídia: a retórica televisiva e suas implicações na identidade nacional, de gênero e religiosa. Antropolítica, 14(2), 61-80.

32. Rial, C. (2008). Rodar: a circulação dos jogadores de futebol brasileiros no exterior. Horizontes Antropológicos, 14(30), 21-65. https://doi.org/10.1590/S0104-71832008000200002

33. Richardson, D., Littlewood, M., Nesti, M., \& Benstead, L. (2012). An examination of the migratory transition of elite young European soccer players to the english premier league. Journal of 
Sport Sciences, $\quad 30(15), \quad$ 1605-1618. https://doi.org/10.1080/02640414.2012.733017

34. Richardson, R., Cowan, C. S., Callaghan, B. L., \& Kan, J. M. (2016). Effects of early-life stress on fear memory in the developing rat. Current Opinion in Behavioral Sciences, 7, 15-20. https://doi.org/10.1016/j.cobeha.2015.10.003

35. Rodrigues, F. X. F. (2010). O fim do passe e as transferências de jogadores Brasileiros em uma época de globalização. Sociologias, 12(24), 338-380. $\quad$ https://doi.org/10.1590/S151745222010000200012

36. Rubio, K. (2010). Jogos olímpicos da era moderna: uma proposta de periodização. Revista Brasileira de Educação Física e Esporte, 24(1), 55-68. https://doi.org/10.1590/S1807-55092010000100006

37. Sebben, A. (2009). O preparo do atleta de futebol. Retrieved May 17, 2015, from http://universidadedofutebol.com.br/andreasebben-psicologa-parte-1/

38. Teixeira, F. (2014). Expatriados Futebol Clube. Belo Horizonte: Editora do autor.

39. Tertuliano, I. W., Oliveira, V., Pavlović, V., \& Machado, A. A. (2018). The need for expatriation and the planning of the process: Organizational looks for sports. Ekonomski Pogledi (Economic Outlook), 20(1), 1-17.

40. Tertuliano, I. W. (2016). Processo de expatriação de voleibolistas: Concepções Bioecológicas. (Doctoral Thesis). Universidade Estadual Paulista, Rio Claro, Brazil.

41. Tertuliano, I. W. (2018). Expatriados e atletas nômades. In F. Rebustini \& A. A. Machado (Eds.), Vulnerabilidade no Esporte: Volume 2 (1st ed., pp. 57-74). Jundiaí: Paco.

42. Tertuliano, I. W., Machado, A. A., Deustch, S., Montiel, J. M., \& Bartholomeu, D. (2018). Motivos e intenções para expatriação de voleibolistas. Revista de Administração Contemporânea, 22(4), 531-551. https://doi.org/10.1590/1982-7849rac2018170032

43. Tertuliano, I. W., Machado, A. A., Oliveira, V., Montiel, J. M., Bartholomeu, D., \& Deutch, S. (2018). Athletic expatriation and volleyball: adaptation to the new club. Manual Therapy, Posturology \& Rehabilitation Journal, 16(626), 1-8. https://doi.org/10.17784/mtprehabjournal.2018.16.626

44. Tertuliano, I. W., Montiel, J. M., Deutsch, S., \& Machado, A. A. (2019). Considerações em relação a expatriação e Globalização: Interfaces com aspectos emocionais. Revista Inteligência Competitiva, 9(1), 15-30. https://doi.org/10.24883/ric.v9i1.300

45. Tertuliano, I. W., Oliveira, V., \& Santana, B. A. (2019). 
Expatriates and international carrer management: corporate and sporting context. Ekonomski pogledi (Economic Outlook), 21(2), $1-17$.

46. Tibbert, S. J., Andersen, M. B., \& Morris, T. (2015). What a difference a "Mentally Toughening" year makes: The acculturation of a rookie. Psychology of Sport and Exercise, 17, 68-78. https://doi.org/10.1016/j.psychsport.2014.10.007

47. Tiesler, N. C. (2016). Three types of transnational players: differing women's football mobility projects in core and developing countries. Revista Brasileira de Ciências do Esporte, 38(2), 201-210. https://doi.org/10.1016/j.rbce.2016.02.015

48. UOL. (2006). Jogadores de Voleibol no exterior formariam 58 equipes. Retrieved January 29, 2016, from http://esporte.uol.com.br/volei/ultimas/2006/12/10/ult1777u57324 .jhtm

49. Vlastuin, J., Almeida, B. S., \& Marchi Júnior, W. (2008). O Marketing Esportivo na gestão do Voleibol brasileiro: Fragmentos teóricos referentes ao processo de espetacularização da modalidade. Revista Brasileira de Ciência do Esporte, 29(3), 924.

50. Weedon, G. (2011). "Glocal boys": exploring experiences of acculturation amongst migrant youth footballers in premier league academies. International Review for the Sociology of Sport, 47(2), 200-216. https://doi.org/10.1177/1012690211399221 